\title{
STRATEGI IMPLEMENTASI ANIMAL WELFARE DALAM PENYEDIAAN PAKAN SAPI BALI
}

\author{
M. A. P. Duarsa, I W. Suarna*), A. A. A. S. Trisnadewi, dan I M. Saka Wijaya \\ 1)Puslitbang Tumbuhan Pakan Universitas Udayana \\ *) corresponding author: wynsuarna@unud.ac.id
}

\begin{abstract}
ABSTRAK
Sesuai amanat sustainable development goals (SDG's) usaha peternakan wajib mengarusutamakan kaedahkaedah pembangunan berkelanjutan yang ramah lingkungan. Peningkatan permintaan akan daging sapi harus diimbangi dengan peningkatan produktivitas sapi untuk memenuhi ketersediaan populasi dan kualitas daging sapi. Kualitas ternak sapi yang dihasilkan sangat tergantung kepada ketersediaan dan kualitas hijauan yang dimakan ternak. Ketersediaan berbagai limbah pertanian dan industri mendorong upaya pengolahan limbah menjadi pakan ternak ruminansia. Limbah yang diolah langsung diberikan kepada ternak ruminansia sebagai pakan alternatif. Limbah biasanya dapat megandung bahan berbahaya, zat anti nutrisi, dan memerlukan biaya yang lebih tinggi untuk mengolahnya. Untuk mengakomodasi kearifan budaya, memelihara harmonisasi spiritualitas bagi petani/peternak, dan menerapkan prinsip-prinsip animal welfare, selayaknya ternak ruminansia seperti sapi bali mendapatkan makanan yang baik yang berasal dari tanaman pakan ternak dengan kualitas yang baik. Dengan demikian limbah harus diolah menjadi pupuk yang berkualitas tinggi sehingga dapat menyediakan hijauan berkualitas bagi ternak sapi bali. Output yang berkualitas menuntut input yang berkualitas juga.
\end{abstract}

Kata kunci: limbah, animal welfare, hijauan berkualitas

\section{STRATEGIC IMPLEMENTATION OF ANIMAL WELFARE IN PROVIDING BALI CATTLE FORAGE}

\begin{abstract}
According to sustainable development goals (SDG's) recommendations animal husbandry activities has to be in line with sustainable development regulation which is environmentally friendly. The increase demand of beef has to be followed by enhancement of cattle production in order to fulfill cattle population and the quality of beef. The quality of cattle depends heavily on the availability and the quality of forage. The availability of agriculture and industry waste endorsing the effort to process these waste to become ruminant feed. Waste can be processed and given directly to the ruminant as an alternative feed. Waste usually contains dangerous compounds, anti-nutrition substances, and needs higher cost for its processing. To accommodate local wisdom, maintaining spiritual harmonious for farmers, and to implement the principals of animal welfare, the ruminants like Bali cattle should have good feed which come from good quality forage. Therefore, wastes should be processed to become high quality fertilizer so that it can provide high quality of forage for Bali cattle. Quality output needs quality input as well.
\end{abstract}

Keywords: waste, animal welfare, quality forage

\section{PENDAHULUAN}

Dunia global telah menyepakati dan meletakkan lima pondasi tujuan pelaksanaan Sustainable Development Goals (SDG's) yakni pembangunan berkelanjutan terhadap manusia, planet, kesejahteraan, perdamaian, dan kemiteraan. Dari 17 tujuan SDG's, tujuan ketigabelas memiliki 5 target, salah satu target diantaranya adalah mengambil tindakan mendesak untuk memerangi perubahan iklim dan dampaknya. Pada tujuan SDG's kelimabelas yang memiliki 12 target, salah satu target diantaranya yaitu melindungi, memperbarui, serta mendorong penggunaan ekosistem daratan yang berkelanjutan, mengelola hutan secara berkelanjutan, memerangi penggurunan, menghentikan dan memulihkan degradasi tanah, serta menghentikan kerugian keanekaragaman hayati. Kedua target yang tertuang pada tujuan ketigabelas dan kelimabelas tersebut sangat erat kaitannya dengan aktivitas antrropogenik dalam sektor pertanian khususnya pada sub sektor peternakan. Manajemen peternakan yang tidak mengikuti 
kaedah-kaedah pembangunan berkelanjutan tak pelak akan memperkuat anggapan bahwa sub sektor peternakan akan berperan sebagai salah satu emiter gas rumah kaca (GRK). Introduksi prinsip-prinsip pembangunan berkelanjutan kedalam manajemen peternakan (terutama ternak ruminansia) akan mampu meminimisasi emisi GRK dan meningkatkan penyerapan GRK dari atmosfir.

Menyediakan pakan yang memadai baik kualitas maupun kuantitasnya sesuai dengan status fisiologis ternak, adalah salah satu upaya bijak dalam manajemen peternakan demikian pula dengan manajemen lainnya seperti penggunaan kandang, pemeliharaan kesehatan, dan menyayangi ternak peliharaan. Penyediaan pakan ternak ruminansia (hijauan dan biji) adalah aktivitas mengumpulkan biomassa asal tanaman makanan ternak dalam system cut and carry atau pada padang penggembalaan. Dengan demikian teknologi budidaya tanaman pakan yang mampu menghasilkan hijauan dan biji berkualitas baik sebagai sumber pakan ternak ruminanmsia merupakan bagian integral dari usaha peternakan ramah lingkungan sekaligus sebagai salah satu upaya mitigasi terhadap perubahan iklim.

\section{KESEJAHTERAAN HEWAN/TERNAK}

Salah satu amanat dari Dokumen SDG's adalah bahwa pada tahun 2030 diharapkan telah terjadi perubahan ke arah perbaikan kondisi lingkungan terutama telah terejawantahkan pelaksanaan berbagai isu strategis yang menjadi program utama melalui kegiatan: memerangi desertifikasi, merestorasi lahan dan tanah terdegradasi, termasuk lahan yang kena dampak desertifikasi, kekeringan, kebanjiran, dan berupaya untuk mencapai dunia yang terdegradasi secara netral. Konservasi ekosistem teresterial, termasuk keaneka ragaman hayati, merupakan keharusan agar dapat meningkatkan kapasitasnya untuk memberikan manfaat yang esensial bagi pembangunan berkelanjutan. Dapat dikatakan bahwa dengan menyediakan lingkungan yang baik dalam usaha peternakan melalui aksi segera dan signifikan dapat mengurangi degradasi natural habitat, dan menghambat hilangnya keanekaragaman hayati, dan mencegah kepunahan spesies terancam/langka.

Lingkungan yang baik dan sehat sesuai amanat Undang-Undang Perlindungan dan Pengelolaan Lingkungan Hidup Nomor 32 tahun 2009 adalah merupakan hak azasi manusia. Dalam konteks perlindungan dan konservasi biodiversitas tentunya lingkungan yang baik dan sehat menjadi kebutuhan yang azasi pula bagi hewan atau ternak peliharaan. Memberikan lingkungan yang baik dan sehat bagi ternak adalah bagian dari aktivitas memberikan kesejahteraan bagi hewan atau ternak tersebut.
Animal welfare atau kesejahteraan hewan/ternak adalah usaha yang timbul dari kepedulian manusia untuk memberikan lingkungan yang sesuai untuk binatang dengan tujuan untuk meningkatkan kualitas hidup hewan/ternak tersebut.

Dalam menerapkan prinsip-prinsip kesejahteraan hewan terdapat lima dasar yang menjadi kebebasan dan harus dimiliki hewan/ternak peliharaan untuk dapat hidup layak dan normal:

1. bebas dari rasa lapar dan haus; ternak harus mendapatkan makanan dan air minum yang cukup memenuhi kuantitas dan kualitasnya

2. bebas dari panas dan rasa tidak nyaman secara fisik: ternak mendapatkan tempat berlindung dari teriknya panas matahari dan terlindung dari bahaya yang selalu mengintai yang dapat menyerang ternak baik induk dan anaknya.

3. bebas dari luka, penyakit dan sakit: ternak harus mendapatkan fasilitas yang memadai seperti misalnya kandang untuk beranak dan kandang untuk ternak dewasa, dan selalu mendapat layanan kesehatan ternak.

4. bebas mengekspresikan perilaku normal dan alami: memberikan lingkungan yang baik dan sehat akan dapat menyenangkan ternak sehingga ternak dapat mengekspresikan prilakunya secara bebas dan sesuai alam kodrati.

5. bebas dari rasa takut dan penderitaan; rasa takut dan penderitaan akan cepat menurunkan bobot badan ternak. Untuk itu ternak harus nyaman dalam pengangkutan (menggunakan kapal ternak), mendapatkan makanan yang sesuai dengan kebutuhannya, dan ternak merasa nyaman karena mendapat perhatian selama dalam proses pengangkutan. Rumah potong hewan juga hendaknya memiliki fasilitas yang memadai sehingga ternak yang akan dipotong tidak mengalami stress berat sebelum dipotong.

Jika salah satu saja dari kelima prinsip dasar kesejahteraan ternak tersebut terabaikan maka akan mengalami kesengsaraan dan semakin jauh dari kehidupan yang sejahtera (Hamka dan FitaIsthayana, 2013).

Selain ihwal kesejahteraan hewan dapat ditelusuri pada UU No.32 tahun 2009 juga dapat ditemui pada Undang Undang No 18 tahun 2009 jo UndangUndang No 41 tahun 2014 tentang Peternakan dan Kesehatan Hewan, kesejahteraan hewan mengandung pengertian bahwa segala urusan yang berhubungan dengan kondisi fisik dan psikis ternak menurut ukuran perilaku alami ternak yang harus diimplementasikan untuk melindungi ternak/hewan dari perlakuan setiap orang yang merenggut kesejahteraan ternak/ hewan peliharaan (Yuliati, 2017). Kesejahteraan hewan memiliki 3 aspek penting yaitu science 
atau mengukur efek pada hewan dalam situasi dan lingkungan yang berbeda dari sudut pandang hewan, etika yaitu mengenai bagaimana sebaiknya manusia memperlakukan hewan, hukum yaitu mengenai bagaimana manusia harus memperlakukan hewan.

\section{FAKTOR PENYEBAB TERABAIKANNYA KESEJAHTERAAN TERNAK}

Implementasi prinsip-prinsip kesejahteraan ternak mendapat tekanan dari berbagai faktor yang sebagian adalah karena aktivitas antropogenik.

1. Peningkatan populasi penduduk dan peningkatan pendapatan masyarakat, cenderung akan meningkatkan alih fungsi lahan sehingga ruang gerak ternak semakin terbatas. Hal tersebut akan dapat mengganggu kenyamanan ternak. Peningkatan penggunaan lahan untuk pemukiman, fasilitas akomodasi pariwisata serta semakin banyaknya kejadian fragmentasi wilayah menyebabkan ternak semakin terhimpit dan tidak dapat mengekspresikan perilaku alaminya.

2. Kebutuhan pasar akan ternak sapi semakin meningkat sehingga banyak ternak sapi yang dijual atau dipotong pada berat ternak belum memadai, sehingga diprediksi akan dapat menurunkan mutu genetik ternak sapi. Eksploitasi irasional terhadap satwa terjadi dimana-mana. Pembiaran terhadap kondisi seperti tersebut akan mempercepat terjadinya kepunahan terhadap sumberdaya plasma nutfah

3. Hanya untuk mendapatkan feses yang lebih banyak, ternak diberikan pakan yang tidak berkualitas sehingga ternak sapi menjadi kurus karena malnutrisi. Kebiasaan ini terjadi dimanamana dan tidak lagi sebagai sesuatu yang ditutup tutupi.

4. Berkembangnya industri pertanian dan industri pengolahan lainnya akan meningkatkan produksi limbah sehingga muncul pemikiran memanfaatkan limbah untuk pakan. Penggunaan limbah untuk pakan hendaknya memperhatikan kesejahteraan ternak dan etika serta nilai-nilai sosial budaya di masyarakat.

5. Semakin terpinggirkan nilai-nilai kearifan budaya yang terpatri dalam pemikiran deep ecology bahwa semua mahluk adalah bersaudara dan berada harmonis dalam satu rumang tangga. Mendoakan ternak sebelum dipotong agar daging ternak dapat meningkatkan derajat hidup manusia dan ternak yang dipotong juga meningkat derajatnya adalah suatu tindakan yang semakin sedikit dilakukan orang. Dalam ajaran Hindu doa untuk ternak yang akan dipotong adalah: Om pasu pasaya wimahe sirascadaya dhimahi tano jiwah pracodayat, yang artinya semoga atas perkenan dan berkahMu para pemotong hewan dalam upacara kurban suci ini beserta orang-orang yang telah berdana punia untuk yadnya ini memperoleh kesejahteraan dan kebahagiaan. Tuhan, hamba memotong hewan ini, semoga rohnya menjadi suci.

Berbagai variabel yang dapat diukur sebagai indikator kesejahteran ternak antara lain adalah: tingkah laku ternak, angka kematian, angka kasus penyakit, angka pertumbuhan, efisiensi reproduksi dan performans ternak. Beberapa kasus yang telah terjadi terkait kesejahteraan ternak antara lain adalah: penyelundupan orang utan dari hutan Indonesia kemudian mempekerjakannya di taman hiburan sebagai petinju, intervensi manusia sangat memengaruhi kelangsungan hidup hewan yang bukan hidup di alam. Dalam hal ini adalah hewan liar dalam kurungan (lembaga konservasi, entertainment, laboratorium), hewan ternak dan hewan potong (ternak besar/kecil), hewan kerja dan hewan kesayangan. Kasus lainnya adalah adanya protes negara lain terhadap prosedur pemotongan sapi yang tidak menerapkan prinsip kesejahteraan ternak.

\section{STRATEGI IMPLEMENTASI KESEJAHTERAAN TERNAK DALAM PENYEDIAAN PAKAN TERNAK SAPI BALI}

Pakan ternak ruminansia dapat berupa hijauan segar, hijauan kering, yang berasal dari tumbuhan pakan bertipe herbasius, semak, dan pohon. Selain hijauan, dari tumbuhan pakan juga dapat diperoleh umbi, buah, dan biji yang sangat bermanfaat bagi ternak ruminansia. Terdapat berbagai jenis tanaman pakan yang juga sebagai tanaman pangan seperti: sorghum, jagung, kedelai, kacang hijau dan sebagainya yang tergolong tumbuhan sereal. Tumbuhan sereal tersebut menyediakan biji-bijian dan hasil sampingannya yang bermanfaat untuk pakan ternak ruminansia dan juga ternak non ruminansia. Sumber pakan ternak juga dapat bersumber dari tanaman pangan dan hasil sampingannya yang masih memiliki kualitas baik sebagai bahan pakan ternak. Secara sederhana sumber pakan dan ketersediaan ternak dapat ditampilkan sebagaimana Gambar 1.

Hijauan yang berkualitas dapat berasal dari tanaman pakan yang unggul, yang memiliki produksi tinggi, nutrisinya tinggi dan seimbang, serta memiliki pertumbuhan kembali yang cepat dan tahan terhadap cekaman lingkungan. Untuk kesejahteraan ternak, wajib memberikan pakan yang berkualitas dan sesuai juga dengan norma dan kearifan lokal di suatu daerah. Gambar 2 berikut menunjukkan adanya 


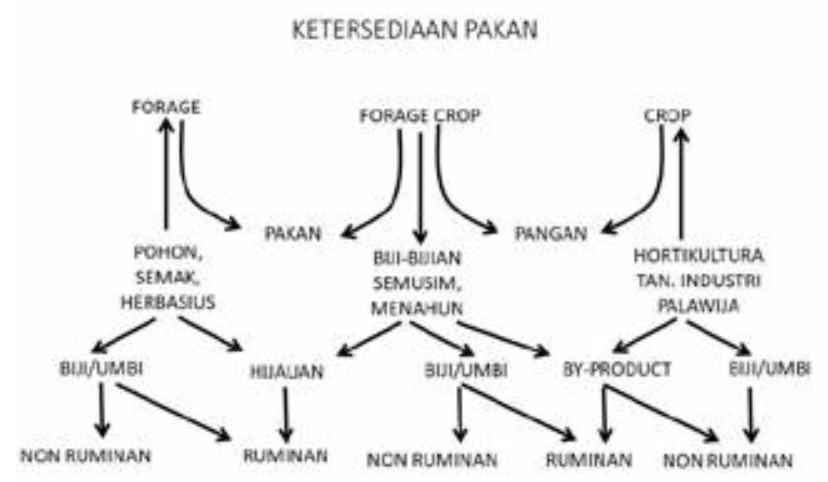

Gambar 1. Ramifikasi pakan ternak

lima komponen penting dalam mengupayakan terwujudnya hijauan dan biji pakan berkualitas (unggul). Limbah sebagai sumberdaya tidak langsung diberikan kepada ternak karena berbagai kelemahan yang sering ditemukan pada limbah seperti: adanya bahan berbahaya dan beracun, zat anti nutrisi dan biaya pengiolahan yang lebih tinggi.

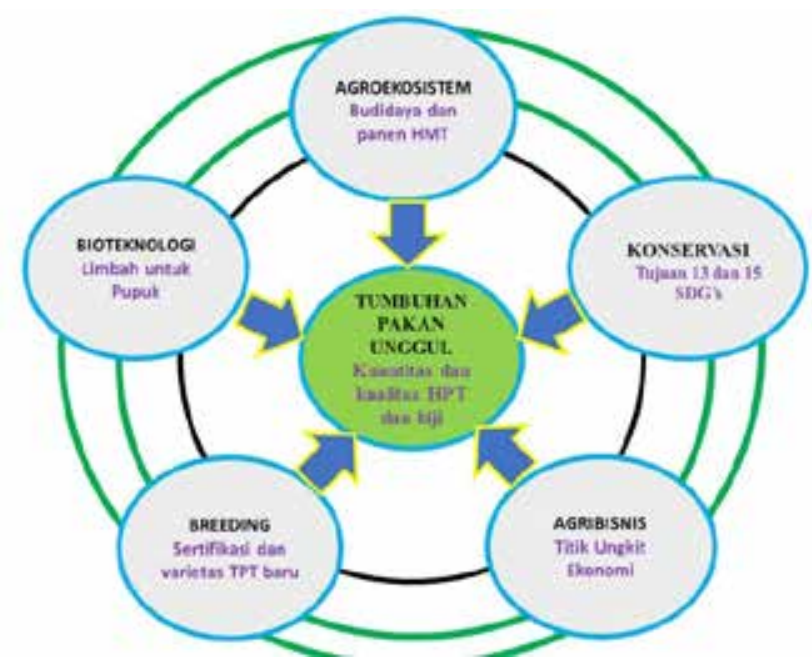

Secara ringkas ada tiga aspek yang perlu dipertimbangkan dalam pemanfaatan limbah sesuai prinsip kesejahteraan ternak yakni: dari sudut pandang filosofis dan keilmuan, dari sudut pandang etika, dan dari sudut pandang teknis manajemen ransum ternak.

1. Filosofis dan keilmuwan

1. Rasional abstract: ternak sapi diagungkan dan dihormati

2. Empiris: menghasilkan susu

3. Menyuburkan tanah

4. Mensejahterakan/membajak

5. Sebagai tabungan masa depan

2. Etika:

1. Ternak sebagai mahluk hidup

2. Input menentukan output

3. Keseimbangan antara hak dengan kewajiban tetapi tidak menyalahi kodrat

4. Etnozoologi

3. Teknis manajemen ransum ternak:

1. Nutrien memadai sesuai status fisiologis

2. Tidak mengandung bahan berbahaya dan beracun

3. Tidak mengandung zat anti nutrisi

4. Pengolahan limbah memerlukan biaya dan tenaga yang banyak

Pada Gambar 3 tampak bahwa limbah industri pertanian dan industri lainnya sebaiknya tidak langsung diolah sebagai bahan pakan tetapi dijadikan bahan baku pupuk yang dengan teknologi pembuatan pupuk ditingkatkan kualitasnya menjadi pupuk yang berkualitas. Melalui teknologi budidaya tanaman pakan pupuk yang berkualitas dapat digunakan untuk meningkatkan kualitas hijauan sehingga ternak mendapatkan hijauan yang berkualitas (Suarna, 2014). Sebagai sebuah ilustrasi dapat disebutkan bahwa sapi bali berumur dua setengah tahun dapat mencapai berat badan $400 \mathrm{~kg}$ lebih dengan pemberian hijauan yang berkualitas dan daily weight gain (DWG) mencapai di atas $1 \mathrm{~kg}$ per hari. Hijauan berkualitas adalah hijauan yang memiliki kandungan protein tinggi dengan kadar serat kasar di bawah $18 \%$. Kriteria tersebut sudah termasuk kedalam katagori konsentrat hijau.

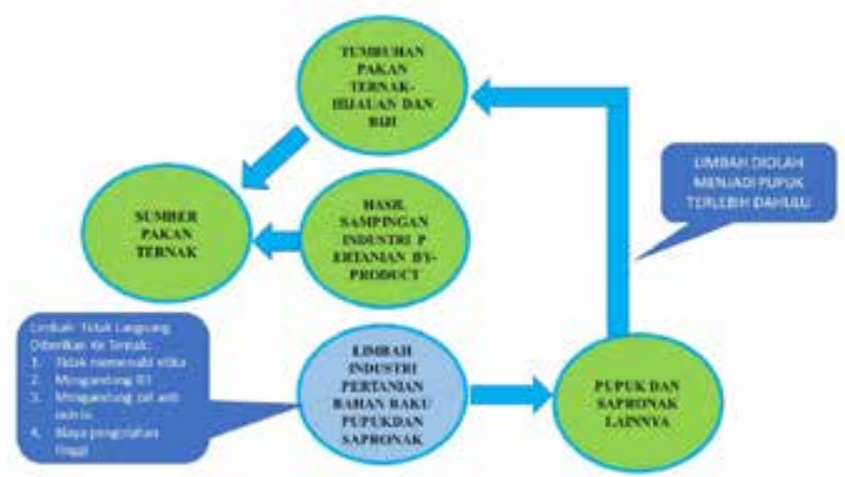

Gambar 3. Strategi penyediaan pakan sesuai prinsip animal welfare

\section{SIMPULAN}

1. Perlu dilakukan revitalisasi kearifan lokal terhadap pelaksanaan prinsip-prinsip animal welfare yang telah membudaya sejak dulu.

2. Melaksanakan animal welfare sekaligus juga merupakan upaya untuk mitigasi perubahan iklim, karena pakan berkualitas akan menurunkan emisi GRK melalui proses sendawa.

3. Limbah sebaiknya dijadikan bahan baku pupuk untuk meningkatkan kualitas hijauan menuju terwujudnya green concentrate yang semakin berkembang dan semakin diminati peternak. 


\section{DAFTAR PUSTAKA}

Hamka dan FitaIsthayana. 2013. Konsep Animal Welfare dan Beberapa Pemikiran. Saturday, May 25, 2013. Dikutip tanggal o1 Nopember 2019

Hindu Mantram. 2014. https://www.facebook.com/ $\mathrm{pg} /$ hindumantras/community/?ref= page_ internal. 29 November 2014. Dikutip tanggal 11 Nopember 2019.

Suarna, I W. 2014. Peternakan Yang Menekan Pencemaran. Prasasti. Denpasar.

Yuliati W. S. 2017. Penerapan Prinsip Animal Welfare dalam Manajemen Pembibitan Ternak di BBPTUHPT Baturraden.Sumber:kominfosandi@ bulelengkab.go.id. Dikutip tanggal o1 Nopember 2019 